\title{
The Study of Consumers' Buying Behavior and Consumer Satisfaction in Beverages Industry in Tainan, Taiwan
}

\author{
Shiau Pei Shih, Szuchiang Yu, and Hui Chin Tseng
}

\begin{abstract}
The beverages industry is the widest base compared to others. A consumer is anyone makes a purchases and transaction decision of goods and services form a store or a company. This study wanted to investigate the consumers' beverage purchasing behavior and their preference for different beverage groups in Tainan City, Taiwan. Descriptive research method was used to survey 150 customers and data were collected through questionnaire administered. Descriptive statistic and Pearson correlation coefficient was used as a method of data analysis. The result of the analysis reveals a positive correlation between product attribute and consumer purchase decision.
\end{abstract}

Index Terms-Purchasing behavior, preference, customer satisfaction, beverages industry

\section{INTRODUCTION}

The beverages industry customer base is probably widest and deepest base in the world. According to Beverage Digest, it has about $85 \%$ consumer base. In fact, the beverages market in Taiwan is about NT $\$ 4,930$ billion which includes water, juice, milk, tea, coffee and other kind energy drinks.

H.Y. Chen (2007) found that beverages are popular commodities in many convenience stores and drinks shops [1]. In today's busy society, everyone has a fast pace of life and everything needs to be done quickly. Therefore we can see 24-hour convenience store everywhere in Taiwan. The major convenience stores are 4,776 of 7-LEVEN until January 22nd 2013, 2,228 of Family Mart and 1,300 of Hi-Life International, Inc (a total of 8,304 stores ).

As the popularity of convenience stores, people are easily purchase daily necessities in the convenience stores in Taiwan. Therefore, the aim of this study wanted to investigate the influence of consumer purchasing behavior on the consumer satisfaction.

Kotler (1977 and 2001) thought that consumer buying behavior is how individuals, groups and organizations to select, purchase, use and disposal of products, services, ideas or experience to meet the consumers' demand. Buying behavior is the decision processes and acts people involved in buying and using products which includes social and mental process [2], [3].

Fornell (1992) pointed out that customer satisfaction is the overall measurement of customers' experience after

Manuscript received October 25, 2013; revised December 27, 2013.

Shiau Pei Shih is with the Far East University, Taiwan (e-mail: jenniferfeu@gmail.com). buying products or using services [4].

\section{LiteratURE REVIEW}

\section{A. Demographic Factors and Consumer Buying} Behavior

See Table I, Kotler (2001) mentioned that demographic factors influenced customer's buying behavior are the internal factors including age, gender, income, occupation, education, family size, and religion, race, generation, nationality and social class, so the market is divided based on these factors. And these factors are the basic factors to differentiate customer groups as the customer wants, preferences and usage are usually involve demographic factors [5].

TABLE I: CONSUMER BUYING BEHAVIOR

\begin{tabular}{|c|c|c|}
\hline Year & Scholar & Definition \\
\hline 1970 & $\begin{array}{l}\text { Walters \& } \\
\text { Paul }\end{array}$ & $\begin{array}{l}\text { People are buying and using the product or } \\
\text { service involved in the decision-making and } \\
\text { behavior [11]. }\end{array}$ \\
\hline 1974 & Pratt & $\begin{array}{l}\text { By cash, check exchange of goods or services } \\
\text { necessary decisions referring to the } \\
\text { purchasing behavior [12]. }\end{array}$ \\
\hline 1983 & Francken & $\begin{array}{l}\text { Consumers are satisfied with the product or } \\
\text { service will generate repeat purchase intention } \\
\text { [13]. }\end{array}$ \\
\hline 2010 & $\begin{array}{l}\text { Shiffman \& } \\
\text { Kannk }\end{array}$ & $\begin{array}{l}\text { Performance in the search for, purchase, use } \\
\text { and evaluate the behavior of products and } \\
\text { services to meet the demand [14]. }\end{array}$ \\
\hline 1993 & $\begin{array}{l}\text { Engel,Blackwell } \\
\& \text { Miniard }\end{array}$ & $\begin{array}{l}\text { Consumer buying behavior is directly related to } \\
\text { the consumption of products and services which } \\
\text { are triggered by the decision-making process } \\
\text { before and after [9]. }\end{array}$ \\
\hline $\begin{array}{l}2005 \\
\& \\
2012\end{array}$ & Kotler & $\begin{array}{l}\text { Consumer buying behavior is how individuals, } \\
\text { groups and organizations to select, purchase, use } \\
\text { and disposal of products, services, ideas or } \\
\text { experience to meet the consumers' demand [15], } \\
{[16] \text {. }}\end{array}$ \\
\hline
\end{tabular}

According to Flynn (1995), age is a very important demographic factors that influences on the decision making process on the purchase behavior because natural factor, easy to measure and use it a lot of social science theories. People of different age have different needs and wants and buy different goods and services over their life time [6].

Dunne and Lusch (1999), the accomplishment in the education field is the most reliable index for the income potential, attitudes and the way of spending of a person [7]. Acton (2005) stated that the consumer purchase behavior is defined as "consumer buying behavior" which is consumed in order to meet the needs of consumers" [8].

Engel (et al., 1993) declared that consumer buying 
behavior is directly related to the consumption of products and services which are triggered by the decision-making process before and after. He also expressed that the purchase behavior of the narrow explanation refers to the buying behavior of individuals substitutes the exchange of goods or services in money or money [9]. East (et al. 2008) said that purchase behavior have been accepted that most repeat purchase decision are done as a habit and often this range of decision-making from rational to automatic is related to the degree of involvement [10].

\section{B. Customer Satisfaction}

According to ISO9000 Quality Management System ( 2001 ) explored that customer satisfaction requirements have been met because of the degree of customer awareness and customer acceptance of its services, including product, service, quality, price and open hours.

See Table II, Cardozo (1965) considered that the raising of customers' satisfactions can increase their purchasing behaviors, further it would also affect for customer to purchase other products [17]. Howard \& Sheth (1969) thought satisfaction is whether customers can get appropriate compensation after purchasing product [18]. East (et al. 2008) believed that customers' satisfaction was an emotional response by product expectations, products performance and the quality [10]. Chi, Wen Hai( 2007 ) thought customers' satisfaction coming from the result of purchase and the service; the better service the higher customers' satisfaction [19]. Fornell (1992) pointed out that customer satisfaction is created by customers' buying experience [4]. Kotler (2009) said that customer satisfaction is a person feeling of pleasure or disappointment about if the perception of the product performance is as well as expectations [20].

TABLE II: CUSTOMER SATISFACTION

\begin{tabular}{|c|c|c|}
\hline Year & Scholar & Definition \\
\hline 1965 & Cardozo & $\begin{array}{l}\text { First scholar proposed the concept of customer } \\
\text { satisfaction [17]. }\end{array}$ \\
\hline 1969 & $\begin{array}{l}\text { Howard \& } \\
\text { Sheth }\end{array}$ & $\begin{array}{l}\text { Customer satisfaction was is whether customers can get } \\
\text { appropriate compensation after purchasing product [18]. }\end{array}$ \\
\hline 1992 & Fornell & $\begin{array}{l}\text { Customer satisfaction was created by customers' buying } \\
\text { experience [4]. }\end{array}$ \\
\hline 2000 & Kotler & $\begin{array}{l}\text { The performances of goods can meet customers' } \\
\text { expectations [21]. }\end{array}$ \\
\hline 2007 & $\begin{array}{l}\text { Chi Wen } \\
\text { Hai }\end{array}$ & The better service the higher customers' satisfactions [19]. \\
\hline 2008 & East & $\begin{array}{l}\text { An emotional response by product expectations, products } \\
\text { performance and the quality of customer services [10]. }\end{array}$ \\
\hline
\end{tabular}

On the basis of literature review, two hypotheses were developed.

1) H1: Consumer buying behavior has significant relationship with consumer satisfaction.

2) H2: Consumer buying behavior has significant influenced consumer satisfaction.

\section{RESEARCH METHODOLOGY}

\section{A. Research Objectives}

1) To know the preference of different group of consumers while purchasing beverages.
2) To know the relationship between consumers buying behavior and consumer satisfaction.

3) To suggest the beverages industry what product items should pay attention.

This study was conducted to investigate the above objectives and also to understand the influence of consumers' beverage buying behavior on consumer satisfaction.

\section{B. The Demographic Characteristics}

In this study, a total of 150 questionnaires were distributed and 150 valid questionnaires were returned and analyzed. From the result of demographic characteristics (see Table III), we can tell male and female is about even-split, the majority of age range is 20-29 years old $(25.2 \%)$ and $30-39(20.3 \%)$, minor age range is $40-49$ $(18.1 \%), 50-60(15.6 \%)$, under $20(13.7 \%)$ and above 60 $(7.1 \%)$; the majority of occupation is student $(33.8 \%)$, manufacturer $(24.9 \%)$ and service/business $(20.8 \%)$, the minor is housekeeper $(12.4 \%)$ and others $(8.1 \%)$; the majority of monthly diet spending is NT2,000-3,999 (33.9\%), NT $\$ 4,000-5,999(32.2 \%)$, the minor is above $\$ 6,000(19 \%)$ and under NT\$2,000 (17.9\%).

TABLE III: THE DEMOGRAPHIC CHARACTERISTICS

\begin{tabular}{|c|c|c|c|c|c|}
\hline & Item. & Percentage & Group of Bottle & Group of Handmade & Group of Self-papend \\
\hline Category, & & $\begin{array}{c}\% .1 \\
(150 \text { total }),\end{array}$ & $\begin{array}{c}\text { drinks }(\%) . \\
\text { (63 interviewees). }\end{array}$ & $\begin{array}{c}\text { drinks }(\%) \\
\text { (55 interviewees), }\end{array}$ & $\begin{array}{c}\text { drinks(\%).। } \\
\text { (32 interviewees). }\end{array}$ \\
\hline \multirow{2}{*}{ Gender. } & Nale, & 493. & 56.8 & 45.6. & 41.4 \\
\hline & Female, & 50.7 & 432. & 54.4 & 58.6 \\
\hline \multirow{6}{*}{ Ages } & Under 20 , & 13.7, & 123. & 10.4 & 5.6. \\
\hline & 20-29, & 252. & 27.8. & 25.6. & 10.2 \\
\hline & $30-39$ & 20.3. & 233. & 27.4 & 12.7 \\
\hline & $40-49$ & 18.1. & 17.1. & 223. & 223. \\
\hline & $50-60$ & 15.6. & 12.7. & 12.2. & 252. \\
\hline & Above 60 & 7.1. & 6.8. & 2.1 & 29.6 \\
\hline \multirow{5}{*}{ Occupation. } & Service Business. & 20.8. & 32.4 & 23.8. & 21.6. \\
\hline & Student. & 33.8. & 20.6. & 33.7. & 12.1 \\
\hline & Manufacturer. & 249 & 265 & 32.6 & 15.8. \\
\hline & Housekeeper. & 12.4 & 15.4, & 18.7. & 224. \\
\hline & Others. & 8.1. & 5.1. & 8.8. & 28.1. \\
\hline \multirow{4}{*}{$\begin{array}{l}\text { Monthly diet } \\
\text { spending. }\end{array}$} & Under NTs2,000. & 179. & 115. & 43. & 19.1. \\
\hline & NTS2,000 - 3,999, & 339 & 39.8. & 25.8. & 35.7 \\
\hline & NTS4,000 - 5,999 & 32. & 28.4, & $32.4 \pi$ & 30.6. \\
\hline & Above NT36,000 & 16. & 20.3. & 375. & 14.6. \\
\hline \multirow{5}{*}{$\begin{array}{l}\text { Weekly consumpion } \\
\text { frequency. }\end{array}$} & 0. & 11.6. & 53. & 42. & 54.8 \\
\hline & $1 \sim 2$. & 319. & 33.8. & 24.7 & 31.4 \\
\hline & $3 \times 4$ & 25.7. & 273. & 32.1 . & 8.7. \\
\hline & $4 \sim 5$ & 182. & 20.7. & 23.4 & 35. \\
\hline & Daily, & 12.6. & 129. & 15.6. & 1.6. \\
\hline
\end{tabular}

The summary of demographic characteristics is as below:

1) Group of bottle drinks: Male is greater than female consumers, the majority age range is under 20 to 39 years old. The majority of occupation is service/business $(32.4 \%)$ and manufacture $(26.5 \%)$, the minor is student $(20.6 \%)$. The majority of monthly diet spending is NT\$2,000-3,999 (39.8\%) and NT\$4000-5,999 (28.4\%) which are higher the average of total.

2) Group of handmade drinks: Female is greater than male consumers, the majority age range is under 20 to 49 years old which is higher than the average of total. The majority of occupation is student (33.7\%) and 
manufactures $(32.6 \%)$. The majority of monthly diet spending is above NT\$6,000 (37.5\%) and NT\$4000-5,999 (32.4\%) which are higher than the average of total.

3) Group of self-prepared drinks: Female is greater than male consumers, the majority age range is older than other groups; above 60 is $29.6 \%$ and 50 to 60 years old is $25.2 \%$ which are higher than the average of total. The majority of occupation is others $(28.1 \%)$ and housekeeper $(22.4 \%)$. The majority of monthly diet spending is NT\$2,000-3,999 (35.7\%) and NT\$4000-5,999 (30.6\%) which are higher than the average of total.

\section{Consumption Frequency of Buying Beverage}

From Table IV, we can see the major consumption frequency is 3 to 4 time a week for handmade drinks $(95.8 \%)$, and minor is bottle drinks $(94.7 \%)$, both groups are higher than the average of total $(88.4 \%)$; the less frequency is self-papered drinks $(45.2 \%)$. The percentage of people enjoying the handmade drinks daily or 4-5 times a week is much higher than others group.

\begin{tabular}{|c|c|c|c|c|c|}
\hline \multicolumn{6}{|c|}{ TABLE IV: CONSUMPTION FREQUENCY } \\
\hline & Times. & Percent & Group of & Group of & Group of \\
\hline & & age \%.। & Bottle.. & Handmade & Self-papered \\
\hline & & $(150$ & drinks $(\%)$ & drinks (\%).। & $\operatorname{drinks}(\%)$. \\
\hline & & total).1. & $(63$ & $(55$ & $(32$ \\
\hline Weekly ., & & & interviewee & interviewees). & interviewees). \\
\hline Consumption & & & 5).1. & & \\
\hline \multirow[t]{5}{*}{ Frequency.s } & 0.1 & 11.6. & 5.3 .1 & 4.2. & 54.8. \\
\hline & $1 \sim 2$. & 31.9 .1 & 32.8. & 24.7 .1 & 31.4 .1 \\
\hline & $3 \sim 4$ & 25.7. & 28.3. & 33.1. & 8.7., \\
\hline & $4 \sim 5$ & 18.2. & 20.7. & 22.4 & 3.5 .1 \\
\hline & Daily., & 12.6. & 12.9. & 15.6. & 1.6 .1 \\
\hline
\end{tabular}

The summary of consumption behavior of buying beverage is handmade drinks are popular and attract lots of consumers to buy, the bottle drinks is the minor, the self-prepared drinks is less attraction and purchase intention than the others two drinks.

\section{The Preference of Beverage Consumption}

Different groups of drink lover have the different ideas and attitudes to health and formula drinks. The health and formula drinks gets the highest preference and support from group of self-papered drinks $(58.5 \%)$ which is greater than the average of the total (42.7) but not the group of handmade drinks $(41.7 \%)$ and bottle drinks (41.3\%).

The study showed that the group of self-papered drinks pays attention on the healthy and formula drinks, the beverages industry can develop or create healthier beverage items to seduce senior consumers to buy for meeting the market demand.

\section{E. Descriptive Statistics and Reliability Test}

Reliability reflects the consistency of participants' responses to the statements of a questionnaire based on the average correlation among those statements. In order to do this, Cronbach Alpha were calculated using SPSS version 17. The reliability statistics for the measurement sets were presented in Table VI. Cronbach Alpha value was acceptable range $\alpha=0.7$ (Girden, 2001).

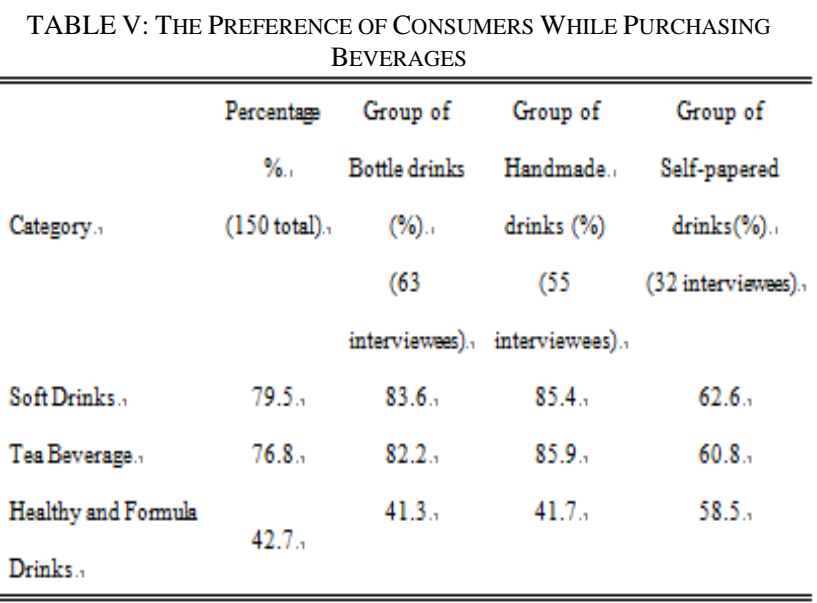

TABLE VI: DESCRIPTIVE STATISTICS AND RELIABILITY TEST

\begin{tabular}{lcccccc}
\hline S/No. & & $\begin{array}{c}\text { No. } \\
\text { of } \\
\text { items }\end{array}$ & Mean & $\begin{array}{c}\text { Std. } \\
\text { Deviation }\end{array}$ & N & $\begin{array}{c}\text { Cronbach } \\
\text { Alpha } \\
\text { Value }\end{array}$ \\
\hline 1 & $\begin{array}{c}\text { Consumer } \\
\text { buying } \\
\text { behavior }\end{array}$ & 4 & 4.74 & .249 & 150 & 0.845 \\
2 & $\begin{array}{c}\text { Consumer } \\
\text { Satisfaction }\end{array}$ & 3 & 4.63 & .292 & 150 & 0.863 \\
\hline \hline
\end{tabular}

TABLE VII: THE CORRELATION ANALYSIS BETWEEN CONSUMER BUYING BEHAVIOR AND CUSTOMER SATISFACTION

\begin{tabular}{|c|c|c|c|}
\hline & & $\begin{array}{l}\text { Consumer } \\
\text { Buying } \\
\text { Behavior }\end{array}$ & $\begin{array}{l}\text { Customer } \\
\text { Satisfaction }\end{array}$ \\
\hline \multirow{4}{*}{$\begin{array}{l}\text { Consumer } \\
\text { Buying Behavior }\end{array}$} & Pearson & 1 & $0.788(* *)$ \\
\hline & Correlation & & \\
\hline & Sig. (2-tailed) & & 0.000 \\
\hline & $N$ & 150 & 150 \\
\hline \multirow{4}{*}{$\begin{array}{l}\text { Customer } \\
\text { Satisfaction }\end{array}$} & Pearson & $0.788(* *)$ & 1 \\
\hline & Correlation & & \\
\hline & Sig. (2-tailed) & 0.000 & \\
\hline & $N$ & 150 & 150 \\
\hline
\end{tabular}

(**). Correlation is significant at the 0.01 level (2-tailed).

TABLE VIII: THE COEFFICIENTS OF CONSUMER BUYING BEHAVIOR AND CUSTOMER SATISFACTION

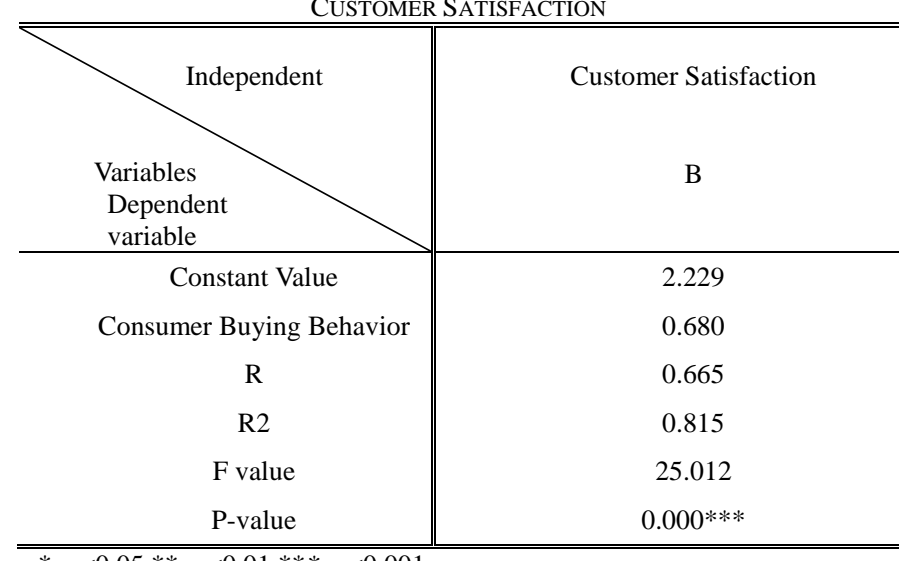




\section{F. Correlation}

Table VII indicates that consumer buying behavior is positively related to the consumer satisfaction with value 0.788 which achieves significant level $(p<0.01)$ and also explains that buying behavior and customer satisfaction has a significant correlation which supports $\mathrm{H} 1$.

\section{G. Multiple Regression Analysis}

Table VIII shows the significant level is .000 which is less than .05. Thus is acceptable and shows strong impact of consumer buying behavior on consumer satisfaction. Hence $\mathrm{H} 2$ is supported.

\section{CONCLUSION AND SUGgeSTION}

From the above the results of statistic analyses, we learne $\mathrm{d}$ that younger female likes handmade drinks, older female 1 ikes self-prepared drinks, only younger male likes bottle dri nks. This study also showed that the frequency of the major consumption is 3 to 4 times a week for handmade drinks, th e less frequency is self-prepared drinks. In addition, this stu dy also demonstrated that there are positive relationship and direct impact for consumer buying behavior and consumer satisfaction in beverage industry.

But the most surprising discovery in this study is that the group of self-prepared drinks pays more attentions and conc ern on the healthy and formula drinks than the group of bott le drink and handmade beverage; the group of self-prepared drinks don't like soft drink and tea beverage as much as the other two groups. Therefore, how to make the healthy and $f$ ormula drinks are adopted by younger groups will be the ke $y$ factors to increase the sales and profit in the beverage ind ustry.

\section{REFERENCES}

[1] H. Y. Chen, "Visual design and application on branding image of Taiwan herbal tea," M.S. thesis, Dept. of Design, National Taiwan Normal Univ., Taipei, Taiwan, 2007.

[2] P. Kotler, "From sales obsession to marketing effectiveness," Harvard Business Review, vol. 55, pp. 67-75, Nov.-Dec., 1977.

[3] P. Kotler and G. Armstrong, Principles of Marketing, 9th ed., N.J.: Prentice Hall, 2001, pp. 32-35.

[4] C. Fornell, "A national customer satisfaction barometer: The Swedish experience," Journal of Marketing, vol. 56, no. 1, pp. 6-21, Jan. 1992.

[5] P. Kotler, A Framework for Marketing Management, 11th ed., N J: Pearson Prentice Hall, 2001, ch. 8, pp. 230-233.

[6] D. O. Flynn and A. Giráldez, "Arbitrage, China, and world trade in the early modem period," Journal of the Economic and Social History of the Orient, vol. 6, no. 2, pp. 429-448, 1995.

[7] P. M. Dunne, R. F. Lusch, and J. R. Carver, Retailing, 7th ed., OH: South-Western Cengage Learnin, 2011, ch. 2, pp. 74-113.

[8] Q. A. Acton, Economics-Advances in Research and Application, 1st ed., Scholarly Edition, 2005, ch. 4, pp. 112-122.
[9] J. F. Engel, R. D. Blackwell, and P. W. Miniard, Consumer Behavior, 7th. ed., NY: Dryden Press, 1993, ch. 4, pp. 156.

[10] R. East, M. Vanhuele, and M.Wright, Consumer Behavior: Applications in Marketing, 1st ed., CA: Sage Publication, 2008, ch. 3, pp. 143-165.

[11] C. G. Walters and W. P. Gorden, Classics of Organizational Behaviors, 10th ed., IL: Waveland Press, 2011, sec. 3, pp. 163-288.

[12] J. W. R. Pratt, "Measuring purchase behavior," Handbook of Marketing, Robert Ferber ed., New York, McGraw-Hill Co., 1974, ch. 5, pp. 171-176.

[13] D. A. Francken, "Postpurchase consumer evaluation, complaint actions and repurchase behavior," Journal of Economic Psychology, vol. 19 , no. 4, pp. 273-290, 1983.

[14] L. G. Schiffman and L. L. Knauk, Consumer Behavior, 10th ed., New Jersey: Prentice Hall, 2010, ch. 1, pp. 20-39.

[15] P. Kotler and G. Armstrong, Marketing: An Introduction, 7th ed., NJ: Pearson Hall, 2005, ch. 1, pp. 6-10.

[16] P. Kotler and G. Armstrong, Principles of Marketing, 14th ed. NJ: Pearson Hall, 2012, ch. 4, pp. 47-63.

[17] R. N. Cardozo, "Experimental study of customer effort, expectation and satisfaction," Journal of Marketing Research, vol. 2, no. 8, pp. 244-249, 1965.

[18] J. A. Howard and J. N. Sheth, The Theory of Buyer Behavior, N.Y.: John Wiley and Sons, 1969, ch. 1, pp. 2-19.

[19] W. H. Chi, Z. Yang, and C. S. He, "The news website service quality, customer satisfaction and loyalty relationship research," Journal of Quality Technology, vol. 14, no. 3, pp. 1-15, Sep. 2007.

[20] P. Kotler and K. L. Keller, Marketing Management, $13^{\text {th }}$ ed., NY: Pearson Prentice Hall, 2009, ch. 11, pp. 378-414

[21] P. Kotler, Marketing Management Millennium, $10^{\text {th }}$ ed., New Jersey: Prentice Hall, 2000, ch. 5, pp. 87-105.

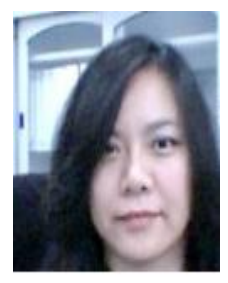

Shiau-Pei Shih was born in Kaohsiung city, Taiwan and her birth date is July 12th, 1968. Ms. Shih has earned one DBA degree from Northwestern Polytechnic University, California, USA in 2011 winter. The research field focuses on a cross-cultural marketing analysis between USA and Taiwan. Dr. Shih has two different majors of master degrees - one was MBA degree from NPU, California, U.S. in 2009 and another was MED degree in MSCS from AU, Ohio, US. in 1995 as well.

Ms. Shih has been teaching in Far East University (FEU) more than 10 years in Taiwan and focusing on the marketing management, strategies and analysis. She used to be the Chief of Teaching Media Production Section in Far East University (FEU), Taiwan and a project manager in Sogo Bakery Co., now she is an assistant professor in Dept. Marketing and Logistics at FEU.

Dr. Shih is the member of PMI (Project Management Institute). Due to her abundant working experience, Dr. Shih leads students groups to win several awards of marketing proposal competition in Taiwan such as Bronze Medal of San John Award, Champion of 2013 Tic Taiwan Award, and Champion of 2013 Product Innovation and Commercialized Award. Her team has received many awards recognizing the excellence performance of the work. She also got twice the best Teaching Awards in FEU.

Szuchiang $\mathbf{Y u}$ is an administrative staff at Northwestern Polytechnic University (NPU), Fremont, California. He received his MSCS degree in 2001 from NPU and served as system administrator afterward. Mr. Yu was promoted and involved campus operations in daily work and was appointed as facility manager later. Now Mr. Yu serves as the director of Operations and IT Affairs in NPU and he is going to earn his MBA degree in spring of 2014 in the near future. 